\title{
Introduction - knowledge-and-ethics: strong curriculum values both, together
}

\author{
Lew Zipin ${ }^{1}$ (D) Marie Brennan ${ }^{1}$ (D) \\ Published online: 11 April 2020 \\ (C) Australian Curriculum Studies Association 2019
}

Keywords Knowledge-and-ethics · Decolonising curriculum $\cdot$ Student activism $\cdot$ Funds of knowledge

\section{Let's not treat the question, "What knowledge?", as first-and-foremost}

Teachers inevitably grapple with ethical questions about the "official knowledge" (Apple 2014) that they are given to work with as 'the curriculum'. Do all students recognise themselves in the knowledge contents of this curriculum? Do learners from diverse family and community contexts find relevant connection to what matters in their lives outside of school? Will they find this knowledge useful in pursuing futures that extend beyond their school years? Does the curriculum stimulate students' senses of purpose and agency to contribute knowledgeably, and caringly - to needs and aspirations of communities with which they identify? Does it capacitate understanding and respect for diverse communities across a multi-cultural, and structurally unequal, broader society? Such questions may not always rise into consciousness among teachers in the thick of learning-and-teaching interactions with students; but we suggest that, implicitly, they pervade those classroom interactions.

Crucially, such questions tie ethics and knowledge together as key dimensions of curriculum activity. What we 'know' is never simply factual, since knowledge is always a social product: it develops in processes of social context and relation. Knowledge is thus always value-laden. Educators therefore need to work to convey both meaning and justice through curriculum - which, suggests social justice philosopher Nancy Fraser (2009, pp. 38-39), requires "full awareness of the internal relations between social knowledge and normative

Lew Zipin

lew.zipin@unisa.edu.au

Marie Brennan

Marie.brennan@unisa.edu.au

1 University of South Australia, Adelaide, Australia [i.e. ethical] reflection". "Full awareness" means that both of these inter-related dimensions - knowledge and ethics - need robust attention, together, in curriculum thinking and practice.

However, prevailing national curricula, such as the Australian Curriculum (AC), seem to derive from heavy emphasis on the question - What knowledge should be selected for curriculum? - without parallel emphasis on ethical questions of justice such as: Whose knowledge matters? Towards what social purposes? And who (what groups) should be represented, how, in what curriculum decision-making processes? (For elaboration on these questions, see Brennan and Zipin 2018.) The AC seems to presume that the first-and-foremost question is 'What knowledge?', which takes care of the other questions without need to enunciate and debate them. And the AC 'answer' appears to be: The 'best' knowledge that we can have - best for all, the same for all - develops among university scholars of distinct disciplines: the STEM disciplines, and those of Social Science, Humanities, Arts, etc. From these disciplines, educational policy-makers should select and organise contents into the discrete academic subjects for school curriculum. Questions of who, how, process and purpose are thus settled within a university-meets-policy nexus (where powerful 'outside' think-tank and corporate influences also weigh; see Reid 2019).

Is university-based disciplinary knowledge - let alone its translations, via policy-makers, into school subjects - as 'culturally neutral' as seems assumed, in relation to a culturally diverse social 'all'? And do schools - under marketcompetition pressures to 'perform' and 'score' in policy's standardised measures that enter into league tables (e.g. Australia's My School website) - really apply official curriculum 'the same' with all students? On the contrary, we find that, especially in secondary schools populated by students from marginalised communities, schools apply the $\mathrm{AC}$ as one among many sorting devices to divide students into 'academically able' as against 'vocational' categories and curricular pathways (see Zipin and Brennan 2019). Such separations 
hardly apply a 'same' curricular treatment to all, let alone justly evaluate, and consider how to work with, the cultural diversities that students embody.

Authors of the five contributions to this Point and Counterpoint affiliate with universities; and they value university-based knowledge as $a$ key source for school curriculum. However, they do not see it as the only or primary source. Their social-justice orientations compel equivalent valuing of culturally rich "funds of knowledge" (Moll 2014; Gonzalez, Moll, and Amanti 2005; Zipin 2013) that young people carry, in "virtual school bags" (Thomson 2002), from their homes and communities into school. Some academic curriculum theorists, with influence on education policymakers, dismiss the value of such knowledge. For example, Young $(2008$, p. 89) argues that

... setting the curriculum apart from the everyday knowledge that students bring to school ... [is what] gives the [university-derived] knowledge acquired through it an explanatory power and capacity for generalization that is not a feature of everyday knowledge tied to practical concerns.

What is more, adds Young (p. 89), curriculum "based on everyday practical experience ... would only recycle that experience".

The authors in this Point and Counterpoint disagree. They see rich potentials for including knowledge from students' diverse life-worlds in curriculum. Argument builds, across their five contributions, not only that life-based knowledge engages, through familiarity, the diverse students who inhabit schools and their local communities. It also brings schools into closer connection with those communities. Moreover, if life-based and university-based knowledge are interacted in curriculum, they mutually enrich and extend the knowledgeable powers that each confers on school learners (Vygotsky 1997/1926), as well as stimulating ethical feelings, understandings and capacities. In this light, the next section briefly discusses each of the five contributions.

\section{Pursuing a knowledge-and-ethics orientation: five contributions}

Decolonising curriculum, to redress injustices of exclusion, is focal to Ann Milne's contribution. Milne outlines an approach developed at Kia Aroha College: a public secondary school in New Zealand with "designated-character" leeway to do curriculum differently with Māori and Pasifika (especially Tongan and Samoan) students. Curriculum activity builds around identities based in students' whānau: their extended families and communities. Milne - a former Kia Aroha principal, now 'retired' - continues to join teachers in working with students who undertake a form of Youth Participatory Action Research, which they call "Warrior Research". The term is inspired by Sitting Bull, a historic native-American tribal leader who explained (as Milne quotes) that "warrior", to his people, does not mean "someone who fights" but who cares for the less powerful, "above all, the children, the future of humanity". Kia Aroha students research vital matters of ethical care for whānau futures: food, health and other poverty-based needs; traumatic legacies of racism; and more. In the process, they learn from, and teach, the teachers working with them. Together they read relevant texts by noted academics, some of whom they meet. Milne recounts a keynote panel of Kia Aroha students who presented, at a NZ education conference, to an academic audience enthused to hear the rich knowledge generated by - not simply transmitted to - these eloquent young people who thus disprove the alltoo-typical 'deficit' perceptions ascribed to their high-poverty and power-marginalised life-worlds. Importantly, their curricular research in/of their communities also pro-actively contributes; for example, as part of investigating food issues, Kia Aroha students researched and supported free local food pantries in their community.

From an Australian Indigenous standpoint, Kevin Lowe and Vilma Galstaun diagnose knowledge contents and organisation of an AC Cross-Curriculum Priority (CCP): "Aboriginal and Torres Strait Islander Histories and Cultures". Their analyses highlight a crucial social-justice principle: cultural-historical recognition. They seek a twofold recognition: that ATSI young people recognise themselves in curriculum; and that non-Indigenous young people gain more authentic understanding of, and respect for, ATSI peoples and their knowledge. However, they find that the AC is dominated by academic subjects that are too compartmentalised: too siloed off from each other as separate disciplines, each with their own norms and logics for selecting and validating knowledge. As a consequence, Indigenous knowledge selected to run 'across' the siloed subject domains is colonised by each discipline's distinctive, and western-centric, epistemologies (ways of knowing). Much knowledge that matters in Indigenous life-worlds cannot, then, find inclusion; and what is forced to 'fit' is atomised, losing the narrative holism which, explain Lowe and Galstaun, is vital to Indigenous ways of knowing. Lowe and Galstaun draw on 'critical incidents': stories of situations in which they worked with pre- and in-service teachers, trying to connect ATSI knowledge into AC subject domains. The obstacles with which they all struggled, argue Lowe and Galstaun, make the case for an inter-disciplinary re-framing that de-colonises curriculum, pedagogy, and teacher-education programs to enable authentically holistic teaching-and-learning that does justice to the cultural-historical richness of Australian Indigenous peoples' ways of knowing. 
Future-oriented student activism is thematic in Eve Mayes' and Roger Holdsworth's contribution. They hail the energies building in student-led activism on global issues across many locales: e.g. school shootings, and strikes for climate action. They highlight the strong feelings expressed in these movements, exemplified in Greta Thunburg's fervent cries for older generations to care about young people's concerns for liveable and socially just futures. Yet politicians and populist media construct these feelings as immature, and young people as vulnerable to left-wing forces that manipulate them to act up when they should be learning wisdoms that come down from adults in schoolrooms. Against this, Mayes and Holdsworth argue for schools to learn from students' 'fervent concerns", as feeling fuel for the (re)making of knowledge in relation to emergent future problems about which what is 'already known' cannot suffice. They discuss curriculum projects in which Student Action Teams have action-researched local issues affecting them and diverse community residents: e.g. community safety issues that link to broader needs for better infrastructure, including participatory-democratic processes by which community voices are heard and their needs resourced. Mayes and Holdsworth do not romanticise younger (or older) people's power to shape futures: they foresee ongoing complex crises that systems of power will continue to deny and/or simplify. Yet, through activism-made-curricular, young people's senses of crisis can convert to knowledgeable critique, feeding "critical hope" (Freire $1992 / 2004$, p. 2) that is vital, argue Mayes and Holdsworth, for an ethical politics wherein citizens can resist simplifications and pursue action on unfolding and complex problems.

Marie Brennan and Helen Widdop Quinton also argue for curricular work that supports students' agency to proact around concerns for futures. Like Lowe and Galstaun, they diagnose the insufficiencies in a Cross-Curriculum Priority: in this case, "Sustainability". Such a huge knowledge area involves complex linkages of planetary climate change with economic, political, social science and humanities domains, calling for inter-disciplinary knowledge work, rather than back-mapping piecemeal bits of selected content into siloed disciplinary domains. Such compartmentalisation, argue Brennan and Widdop Quinton, relegates to the margins young people's ethically impelled desires to fathom and address human and planetary futures. In re-imagining curriculum frames that could support student-teacher-school-community collaborations to build ethically activated knowledge for pursuing planetary futures, the authors draw on a range of curriculum approaches that already have histories. These include work with Indigenous peoples' ways of knowing in relation to Country, and a variety of place-based curricula and pedagogies that actively connect students' and teachers' knowledge work with local environmental and community spaces and issues. The authors argue for the importance of seeing past a view of ethics as only private and personal, through explicit and shared reflection on ethical relations among diverse human cultures, other species and ecosystems. Curriculum would thus explore tensions and possibilities for ethical approaches to planetary futures. The authors suggest that such ethical recognition of diversity can build through research, and follow-up action, that galvanises students' and teachers' knowledge work around problems that matter to futures of all involved.

A "Problems that Matter" (PTM) approach is how Zipin names an impulse, running across all five contributions, for curriculum that interacts diverse knowledge around mattering problems in students' life-worlds. This approach extends from a Funds of Knowledge approach that originated in high-poverty Mexican-American regions of the U.S. southwest (Gonzalez et al. 2005), where teachers and university academics researched together for cultural resources ('funds') of meaningful use-value in students' homes and communities, around which they designed curriculum units that connected into/across school subjects. Zipin's PTM extension: (a) focuses the research for funds of knowledge, and its curricular links to academic knowledge, around mattering problems that students identify in their locales; and (b) brings students and community residents into active research collaboration with teachers and academics. Zipin illustrates the approach in an imagined scenario that draws on, and extrapolates beyond, Australian Funds of Knowledge projects in which he was involved. His scenario targets the PTM of chronic floods in a rural Queensland region. Research on this PTM moves across classroom and community spaces and features dialogic inter-actions - working towards proaction - as the diverse participants share experience and knowledge about floods. Zipin highlights how the PTM attracts a complex mix of knowledge: it holds different meanings to students and community residents from diverse social-cultural groups; and it weaves environmental, socio-economic, ethnic-'racial', gendered and other relational dynamics. Zipin appreciates that, in the current policy climate, few schools are set up to support a fully robust PTM approach; he suggests a "pragmatic-radical" ethics for schools to expand their possibilities in strategic steps and stages.

\section{Curriculum that enacts a dynamic ethics-and-knowledge}

In the first section of this Introduction, we argued for thinking knowledge-and-ethics, together. We suggested that such 
thinking pushes questions about curriculum beyond 'What knowledge?', into questions of 'Whose knowledge?'; 'For what social purposes?'; 'Decided by who, and how?' These questions evoke a social justice framing (Fraser 2009) in which, across - and respecting - social diversities, principles of equality in terms of cultural recognition, inclusive representation, and participatory agency are paramount. These are huge, and hard, questions and principles to address in thought, let alone in schooling practice. Yet, the five contributions to this $\mathrm{P} \& \mathrm{C}$ each elaborate ways - briefly digested in the second section above, and elaborated in the full articles that follow. In this concluding section of our Introduction, we want to highlight some implications of the five contributions, which we believe can help educators consciously to connect ethics and knowledge together, dynamically, in the work of curriculum.

- Young people in schools deserve opportunities to engage with diverse ways of knowing and being in the world, including those of their communities, and those of other communities.

- It is a key issue of justice that the currently marginalised knowledges of colonised First Peoples gain recognition through meaningful inclusion in curriculum: so that young people from their communities recognise themselves in curriculum that supports their identities; and so that others learn from those historic and continuing place-based knowledges.

- The multiple challenges facing humanity and the planet locally and globally - are emergent, not fixed. They continually generate new conditions, considerations, and complex combinations that already existing knowledge cannot simply grasp. The complexities of these 'problems that matter' - especially for futures of young people - call for interdisciplinary curricular engagement. Further, they call for connecting knowledge from community life-worlds with academic knowledge, so that all who are affected can contribute to understandings and options for action.

- In this context, curriculum needs to be both futureoriented and action-oriented. Curriculum in practice should be understood as, most fundamentally, a dynamic process of working with and on knowledge. In this way, both students and teachers recognise themselves as knowledge-making agents.

- Working on complex problems of local-and-global urgency attracts interest and engagement of diverse people who feel affected and who have experience and knowledge to contribute. This can include people from diverse communities, and from diverse fields of specialist knowledge, to work with students and teachers. Mattering problems, then, attract a "dialogic democracy" (Callon, Lascoumes, and Barthe 2009) across diverse knowledges, such that all who participate both learn and teach, contributing to each others' knowledge-abilities. Student-led action-research projects, working between community and school spaces, offer promising possibilities to build problemfocused collaborations.

As already noted, the current climate of educational policy, and associated institutional constraints in schools, pose barriers to robust follow-through on the ethical impulses outlined above. The five contributions that follow recognise these barriers; indeed, they analyse many of them. Yet across the set of papers are both strategies and illustrations for gaining traction on curriculum that brings ethics and knowledge into robust interaction. We invite readers, in engaging with the papers, to imagine how, in your spaces of educational practice, you might find collegial will and desire, and other affordances, to bring ethics-and-knowledge into dynamic possibility.

Acknowledgements The guest editors and authors for this Point and Counterpoint would like to acknowledge the generosity and expertise of the blind reviewers for each of the articles.

\section{References}

Apple, M. W. (2014). Official knowledge: Democratic education in a conservative age (3rd ed.). New York: Routledge.

Brennan, M., \& Zipin, L. (2018). Curriculum for all? Exploring potentials for (in)justice in the Australian curriculum. In A. Reid \& D. Price (Eds.), The Australian curriculum: Promises, problems and possibilities (pp. 179-187). Canberra: Australian Curriculum Studies Association.

Callon, M., Lascoumes, P., \& Barthe, Y. (2009). Acting in an uncertain world: An essay on technical democracy. Cambridge: The MIT Press.

Fraser, N. (2009). Scales of justice: Reimagining political space in a globalizing world. New York: Columbia University Press.

Freire, P. (1992/2004). Pedagogy of hope: Reliving pedagogy of the oppressed (R. B. Barr, Trans.). London: Continuum.

Gonzalez, N., Moll, L. C., \& Amanti, C. (Eds.). (2005). Funds of knowledge: Theorizing practices in households, communities and classrooms. Mahwah: Lawrence Erlbaum Associates.

Moll, L. (2014). L.S. Vygotsky and education. Hoboken: Taylor and Francis.

Reid, A. (2019). Changing Australian education: How policy is taking us backwards and what can be done about it. Sydney: Allen \& Unwin.

Thomson, P. (2002). Schooling the rustbelt kids: Making the difference in changing times. Sydney: Allen \& Unwin.

Vygotsky, L.S. (1997/1926). Educational psychology. Boca Raton: CRC Press.

Young, M. (2008). Bringing knowledge back in: From social constructivism to social realism in the sociology of education. Milton Park: Routledge.

Zipin, L. (2013). Engaging middle years learners by making their communities curricular: A funds of knowledge approach. Curriculum Perspectives, 33(2), 1-12.

Zipin, L., \& Brennan, M. (2019). Pursuing pragmatic-radical curriculum democracy: Students as co-researchers on problems that matter. In $\mathrm{S}$. Riddle \& M. W. Apple (Eds.), Re-imagining education for democracy (pp. 56-73). London: Routledge.

Publisher's note Springer Nature remains neutral with regard to jurisdictional claims in published maps and institutional affiliations. 